\title{
KUMULOWANIE MAŁYCH PAMIĘCI. ŚWIAT OBRAZÓW CHRISTIANA BOLTANSKIEGO W GALERII FOKSAL
}

Christian Boltanski, jeden z najbardziej znanych współczesnych artystów francuskich, określa swoje prace jako malarskie, choć najważniejszym dla niego medium jest fotografia. Pozwala mu ona materializować myśli w sposób nieprzypadkowy (który może ujawnić się w pociągnięciu pędzla), a jednocześnie skupić się całkiem na temacie vanitas. Tworząc swój fascynujący świat obrazów, konfrontuje z sobą doświadczenie indywidualne i przesłanie uniwersalne. Jak sam opowiada: każdy z nas jest skomplikowany, a potem... po prostu umiera. Jednego dnia jest podmiotem, a następnie staje się ,przedmiotem, który można podnieść jak kamień, choć ten kamień był kiedyś kimś" (cyt. za: Kowalski 183). Sztuka francuskiego twórcy niewątpliwie budzi gorące emocje, on sam zaś zdaje się przed nami otwierać, już na początku swej drogi artystycznej prezentując „wszystko”, jak twierdzi, co pozostało z jego dzieciństwa. To graniczny punkt wyjścia do tego, czym zajmuje się do dziś: zawiera wszystko, co od tamtej pory stworzył.

Niniejszy tekst jest próbą spojrzenia na tę metodę twórczą, w której kluczową rolę odgrywa właśnie fotografia - „sztuka rzeczywistości”. Proponowana tutaj perspektywa odnosi się w szczególności do związków Boltanskiego z Polską i jego współpracy z warszawską Galerią Foksal. Wydaje się bowiem, że w wystawach realizowanych w ciagu trzydziestu lat w Warszawie skupiają się najważniejsze wątki jego bogatej twórczości. Przekonanie o niemożności uniknięcia śmierci, o niemożności zachowania czegokolwiek popycha artystę do fotografii. Za jej pomocą raz po raz mierzy się z procesem

Dr Anna Dzierżyc-Horniak - Katolicki Uniwersytet Lubelski Jana Pawła II, Wydział Nauk Humanistycznych, Instytut Nauk o Sztuce, Katedra Badań nad Sztuką od Starożytności do Współczesności; adres do korespondencji: Al. Racławickie 14, 20-0950 Lublin; e-mail: anna.dzierzyc-horniak@kul.pl; ORCID: https://orcid.org/0000-0002-6552-6201. 
zamiany podmiotu w przedmiot, i to nie raz widać na Foksal. Podjęta analiza będzie ukierunkowana na specyficzne rozumienie fotografii czy raczej myślenia fotografią - co w przypadku Boltanskiego jawi się jako najtrafniejsze.

\section{FRANCJA, POLSKA, A MOŻE EUROPA WSCHODNIA?}

Dlaczego właśnie Galeria Foksal ma tu służyć jako swego rodzaju model dla praktyki artystycznej Boltanskiego? Powodów jest wiele. To właśnie w tej niewielkiej, 40-metrowej galerii, znajdującej się w oficynie Pałacu Zamoyskich w Warszawie, francuski twórca wystawiał w Polsce najczęściej, bo czterokrotnie ${ }^{1}$. Pojawił się tu po raz pierwszy na wspólnej wystawie z Anette Messager - dokładnie dziesięć lat po swoim indywidualnym debiucie w paryskim kinie Cinéma Le Ranelagh (1968). Miał już za sobą pokazy w takich liczących się dla sztuki miejscach, jak Galerie Sonnabend w Paryżu (1971, 1974, 1975, 1976, 1977) i Nowym Jorku (1973, 1975, 1976), Muzeum Sztuki Nowoczesnej Miasta Paryża (1970), Centre George Pompidou (1976) czy też na Documenta w Kassel $(1972,1977)$ oraz Biennale w Wenecji (1972). Dla samej galerii to również dużo znaczyło, gdyż z każdym kolejnym rokiem zyskiwał coraz większą sławę i znaczenie jako jeden z najważniejszych twórców z kraju nad Sekwaną. W ustanowieniu tych bliskich relacji Boltanskiego z Galerią Foksal kluczową rolę odegrały przede wszystkim dwie osoby: Tadeusz Kantor, którego twórczość (głównie teatralną) ogromnie cenił francuski artysta, oraz Wiesław Borowski, krytyk sztuki, współzałożyciel warszawskiej galerii, związany z nią przez 40 lat.

Borowski wspominał, że wiedzieli i czytali o Boltanskim już pod koniec lat 60. Kantor, będąc w Paryżu, widział wystawę, którą artysta miał razem z Jeanem Le Gacem. Entuzjastycznie później o niej opowiadał w środowisku

\footnotetext{
${ }^{1}$ Warto dla porównania przywołać indywidualne wystawy Boltanskiego w innych miejscach w Polsce: Kronika wypadków 1973, B.W.A. Lublin, 1978; Revenir, CSW Zamek Ujazdowski, Warszawa, 2001; Les archives du cœur / Archiwum Serc, CSW Zamek Ujazdowski, Warszawa, 2011; Christian Boltanski. W mgnieniu oka / In the Blink of an Eye, Ośrodek Dokumentacji Sztuki Tadeusza Kantora CRICOTEKA, Kraków, 2015. Aby mieć pełny obraz sytuacji, do tego zestawienia można dodać wystawy zbiorowe, w których francuski artysta uczestniczył: C.D.N., Galeria Współczesna, Warszawa, 1974; Francja dzisiaj, Muzeum Narodowe, Warszawa, 1990, Muzeum Narodowe, Kraków, 1991; Musée d'Art Contemporain, Lyon. Kolekcja - Collection, Muzeum Sztuki, Lódź, 1992; Gdzie jest brat twój, Abel?, GSW Zachęta, Warszawa, 1995; Les paradoxes du réel, la réalité des utopies, GSW Zachęta, Warszawa, 1998; International Collection of Contemporary Art. $5^{\text {th }}$ Edition, CSW Zamek Ujazdowski, Warszawa, 2009; Zbrodnia w sztuce / Crime in Art, MOCAK, Kraków, 2015.
} 
Galerii Foksal, a jego uwagę zwrócił właśnie Boltanski. Borowski z kolei zainteresował się nim po lekturze jednego z wywiadów (Borowski 429)². Do pierwszego spotkania doszło w 1977 r., kiedy to Kantor i jego Teatr Cricot 2 wystąpił ze spektaklem Umarła klasa na Jesieni Paryskiej w Théâtre National de Chaillot. Chciał, by Boltanski zobaczył przedstawienie. Poszukiwania w Paryżu prowadził Borowski, co prawdopodobnie nie było takie trudne (,środowisko twórców awangardowych było bardzo małe”), tym bardziej że francuski twórca przyjaźnił się z Aliną Szapocznikow i jej mężem Romanem Cieślewiczem („może oni dali namiary na mnie?”) („Polański tak, Uklański - nie!" 48) ${ }^{3}$. Po powrocie do Polski Borowski napisał do Boltanskiego i do Messager (jego partnerki życiowej od końca lat 60.), a ci szybko zareagowali. Ich przyjazd wsparł Instytut Francuski i w ten sposób doszło do po pierwszej wystawy artysty w Galerii Foksal. Boltanski nie mógł i nie chciał odmówić. Wydaje się, że ważną rolę w tym wszystkim odegrał również Tadeusz Kantor, mocno zaangażowany wówczas w sprawy warszawskiej galerii. Krakowski artysta, jak wyjaśniał Boltanski:

dla środowiska artystycznego we Francji był bogiem. Jako artysta zawdzięczam mu najwięcej. Rozwijał ten sam pomysł, którym i ja się zająłem. Odkrył, że w każdym $\mathrm{z}$ nas tkwi nieżywe dziecko, badał naturę wspomnień, pytał, czy przedmioty mogą powiedzieć coś o człowieku. („Polański tak, Uklański - nie!” 48)

W ten sposób zawiązały się artystyczne znajomości. Wiesław Borowski tak to komentowat:

W latach 70. byliśmy bardzo zaangażowani w prace artystów, którzy współpracowali z galerią. O każdym z nich można by opowiadać bardzo długo: Weiner, Tom Marioni, Boltanski, Annette Messager, John Hilliard, Giovani Anselmo - oni wszyscy czuli związek z galerią, spotykaliśmy się zawsze za granicą, kiedy zdarzało się, że mogłem ich odwiedzić. (Borowski 418-419)

Borowski, będąc w Paryżu, spotykał się z Boltanskim, najczęściej w bistro koło Beaubourg. Z kolei Boltanski opowiadał, że gdy do Paryża przy-

${ }^{2}$ W Archiwum Galerii Foksal, w skrzynce poświęconej Christianowi Boltanskiemu można znaleźć m.in. przetłumaczony tekst Catharine Millet (26).

${ }^{3}$ Christian Boltanski mieszka od lat w Malakoff pod Paryżem. Tam zawsze przebywało dużo artystów, oczywiście Anette Messager, a także m.in. właśnie Alina Szapocznikow, Sophie Calle, Pablo Reinoso, Sam Szafran i Angelika Markul (polska artystka, uczennica Boltanskiego, współpracująca z nim przez kilka lat). Co ciekawe, do Malakoff jeszcze przed poznaniem Boltanskiego trafili Kantor z Borowskim. Był rok 1971, w Théâtre 71 na Malakoff wystąpił Cricot 2 ze spektaklem Kurka Wodna. Dla Borowskiego, który bardzo często w dekadzie lat 70. towarzyszył Kantorowi w jego podróżach teatralnych, był to pierwszy taki wyjazd. 
jeżdżał twórca Umarłej klasy, to zabierał go na wycieczkę po knajpach i pracowniach artystów, że towarzyszył mu w tournée, że stawał się wówczas częścią jego świty (choć „słowo «przyjaźń» w przypadku Tadeusza Kantora trzeba traktować dosyć umownie”) („Polański tak, Uklański - nie!” 48). Można tu też przywołać nocne długie rozmowy Borowskiego z Boltanskim w Warszawie, gdy siedział wraz z nim u Andrzeja Turowskiego, współpracującego z galerią historyka sztuki. Rozmowy dotyczyły i polityki, i sztuki Boltanski rekomendował na przykład angielskiego rzeźbiarza Billa Woodrowa (choć akurat do tej wystawy nie doszło, mimo spotkania i dobrego porozumienia Borowskiego z artystą) (Borowski 371, 398). W tym kręgu uczestniczyła również Annette Messager. Po długiej przerwie miała ona swoją drugą wystawę na Foksal - Parade (1995), w której organizacji pomogła Ewa Franus, historyczka i krytyczka sztuki oraz tłumaczka, partnerka Turowskiego. Borowski tak to wspominał:

Wczesne lata 90. Pojechałem do Paryża, żeby prosić ją [Messager] o wystawę. Spotykaliśmy się w kafejce. Była cudowna, mówiła, że jest bardzo zajęta robieniem wystaw, wykładała też $\mathrm{w}$ tej samej szkole, co Boltanski i Buren. Powiedziałem: „Annette, musisz przyjechać i mieć u nas wystawę”. Odpowiedziała, że zrobi to dla mnie. (Borowski 373$)^{4}$

Nic więc dziwnego, że gdy w połowie lat 80. podczas rozmowy Olle Granatha $\mathrm{z}$ Wiesławem Borowskim pojawił się pomysł organizacji wystawy polskich artystów w Moderna Museet w Sztokholmie (i żeby to była wystawa międzynarodowa), to Boltanski stał się jednym z jej uczestników. Główną jej ideą był tytułowy „dialog”, do którego polscy twórcy mieli zaprosić najciekawszych dla nich artystów z całego świata. Maria Stangret, żona Kantora, a zarazem współzałożycielka Galerii Foksal, stworzyła artystyczną parę właśnie z Boltanskim ${ }^{5}$.

Warto w tym miejscu zwrócić uwagę na fakt, o czym pisał Grzegorz Kowalski, że debiut francuskiego artysty w warszawskiej galerii przypadał na rok 1978, co wcale nie było tak późno, pamiętając ówczesny podział Europy.

\footnotetext{
${ }^{4}$ Szkołą, o której wspominał Borowski, była École nationale supérieure des beaux-art (Państwowa Wyższa Szkoła Sztuk Pięknych) w Paryżu.

${ }^{5}$ Co ciekawe, Boltanski cenił ogromnie malarstwo Stangret, pomijając w tym aspekcie Kantora, choć wielbił go jako artystę teatralnego (Borowski 263-264). W organizację wystawy Dialog, która miała miejsce w dniach 7 września - 20 października 1985 r., włączyli się również Ryszard Stanisławski, Milada Ślizinska, Anka Ptaszkowska. Uczestniczyli w niej tacy artyści, jak: Henryk Stażewski - Daniel Buren, Edward Krasinski - Lars Englind, Lesław i Wacław Jannicy - Gilbet \& George. Por. „Dialog”.
} 
Aby wystawa w Galerii Foksal mogła zaistnieć, musiało dojść do połączenia dwóch determinant: ciekawości lub sympatii artysty dla naszej części Europy oraz ambicji ludzi galerii, którzy od polowy lat 60. ubiegłego wieku chętnie prezentowali przejawy ,eliminacji sztuki w sztuce”, polskiej odmiany konceptualizmu. (...) Ale dla mnie artystyczna zawartość wystawy jest drugoplanowa. Kto pamięta czasy żelaznej kurtyny, wie, ile determinacji wymagały kontakty między ludźmi żyjącymi po obu jej stronach. Jaką upokarzającą cenę płaciliśmy za paszport i jakie to było egzotyczne dla obserwatorów z Zachodu. To następny, obecnie już historyczny, dowód na nieprzystawalność sztuki powstającej w warunkach wolności we Francji i w warunkach informacyjnej luki, izolacji i politycznej opresji w Polsce. (Kowalski 182)

Słowa z laudacji doktoratu honoris causa dla Boltanskiego na poznańskiej ASP dobrze obrazują ówczesną sytuację, z którą musieli się zmagać prowadzący galerię krytycy sztuki. Remedium na to stały się osobiste kontakty, które w dużej mierze przekładały się na artystyczne projekty. Nastąpiło to wyraźnie obok obowiązującej polityki kulturalnej, co - paradoksalnie - pozwoliło środowisku galerii znaleźć się w międzynarodowym obiegu sztuki na skalę porównywalną $\mathrm{w}$ tamtym czasie jedynie do łódzkiego $\mathrm{Mu}$ zeum Sztuki (które miało przecież zupełnie inną „moc instytucjonalną”). Galeria Foksal z jednej strony funkcjonowała niejako na obrzeżach (,poza głównymi szlakami”) zachodniej sztuki, a zarazem jej sytuacja w Polsce była podobna, na granicy oficjalnego i zatwierdzonego życia kulturalnego.

To wszystko sprawiło, że dla Boltanskiego przyjazd w 1978 r. do Polski i wystawa w Galerii Foksal okazały się bardzo ważne. Z jednej strony poznawał środowisko skupione wokół Kantora i Borowskiego, siedział z nimi w Hotelu Europejskim, pił i rozmawiał o tym samym, o czym się rozmawiało w Paryżu czy Nowym Yorku. Z drugiej strony, jak opowiadał, czuł też oddech komunistycznego absurdu. Oto bowiem, żeby zapłacić za pobyt jego i Messager, Borowski musiał dogadać się z Muzeum Sztuki w Łodzi, aby kupiło ich pracę. Boltanski deklarował:

Od tamtego czasu postrzegam Polskę jako drugą ojczyznę. Wiem, że to mitologizowanie, ale każdy ma dla siebie jakiś wymarzony kraj, nierzeczywisty, i tym krajem dla mnie jest Polska. Uważam się raczej za artystę z Europy Wschodniej, która zaczyna się w Niemczech, niż za reprezentanta sztuki zachodniej. Dlaczego? - Sztuka francuska to inteligencja i dobry gust, czyli Marcel Duchamp i Henri Matisse. A ja czuję się ekspresjonistą, opowiadam ludziom historię nie słowami, ale emocjami, chcę, by te opowiastki prowokowały do stawiania pytań. Blisko mi do Piny Bausch czy Kantora. Swoją wystawę w CSW w 2001 roku nazwałem „Revenir”, czyli „Wracać”. („Polański tak, Uklański - nie!” 48) 


\section{OD DZIECIECCYCH MODELI I ZABAWEK PO PULSUJĄCE SERCE ARTYSTY}

Przygoda Christiana Boltanskiego z polską publicznością rozpoczęła się zatem w 1978 r. W czerwcu artysta miał wystawę Kronika wypadków 1973 w lubelskim BWA (Christian Boltanski [bez stron]), a miesiąc później w warszawskiej Galerii Foksal - Les images stimuli ${ }^{6}$. Równolegle z Boltanskim na Foksal wystawiała Annette Messager. Francuski artysta przedstawił wówczas trzy cykle fotografii oraz slajdy wyświetlane na ścianie. Na Les images modeli składały się charakterystyczne polaroidowe kolorowe zdjęcia naklejone na trzy plansze. „Modelami” były dzieci bawiące się na dworze, jedna $z$ fotografii przedstawiała na przykład dziewczynkę na hulajnodze na betonowym placu, inna stanowiła portretowe zbliżenie innej dziewczynki, odwróconej, lekko uśmiechającej się do aparatu. Le Club Mickey to już kolekcja czarno-białych portretów dzieci, w wieku około dziesieciu lat, $\mathrm{w}$ różnych układach. Kilkanaście $\mathrm{z}$ nich pokazywało powtarzane ujęcie chłopców i dziewczynek sfotografowanych na tle wejścia do tego samego budynku (il. 1). Część z tego zbioru stanowiły również zdjęcia legitymacyjne, były i fotografie amatorskie dzieci ujętych w różnych pozach, stojących ze swoimi rowerkami, przytulonych do zwierząt, grających na pianinie. Wszystkie zostały powiększone, co nadało reprodukcjom charakterystyczną nieostrość, wywołaną dużym ziarnem. Tak naprawdę nie wiemy, kim są te wszystkie dzieci, jedynie nazwa cyklu - i jedno zdjęcie z dziewczynką trzymającą pluszową maskotkę - sugeruje, że mogą to być członkowie szkolnych klubów Myszki Miki, które powstawały na fali popularności telewizyjnego programu muzycznego emitowanego w drugiej połowie lat 50 . Tytułowy trzeci cykl, czyli Les images stimuli, przedstawiał fotografie „dziecięcych skarbów”. Każde zdjęcie skupiało się na jednym przedmiocie, który

\footnotetext{
${ }^{6}$ Wystawy Christiana Boltanskiego Les images stimuli i Annette Messager Serials były prezentowane w Galerii Foksal równocześnie od 13 lipca 1978 r.

${ }^{7}$ Pierwszy A Mickey Mouse Club powstał w Stanach Zjednoczonych w 1929 r., rok po powstaniu postaci słynnej animowanej Myszki, będącej od początku symbolem amerykańskiego optymizmu i energii. W latach 30. firma Disney stała się światowym potentatem, a ludzie na całym świecie pokochali Myszkę Miki - świat ogarnęła mikomania. Sympatycy animowanej postaci spotykali się w klubach, by wspólnie oglądać bajki i dzielić się wrażeniami. Myszka odnalazła się także w erze telewizji. Gdy w 1955 r. stacja ABC rozpoczęła nadawanie The Mickey Mouse Club (do 1959 r., a następnie w latach 70., 90. i od 2016), program stał się najbardziej popularną audycją dla dzieci w historii telewizji. Por. Kuc; Zaranek. Do tematu klubów Myszki Miki Boltanski powrócił w latach 90., zestawiając z tych zdjęć książkę artystyczną Le Club Mickey (1990).
} 
zajmował cały kadr na jednobarwnym tle. Znalazły się tutaj takie „reprezentacje", jak miseczka z czekoladą, bile do gry w bilard, ciasto w foremce, figurka kowboja, jajko na twardo, butelka kleju, herbatniki, puzzle, jogurt, figurki hodowcy i zwierząt hodowlanych, lizak, tabliczka czekolady, piłka, cukierki. Tych szesnaście fotografii zostało wzmocnionych podobnymi barwnymi slajdami wyświetlanymi na ścianę galerii (il. 2). Na slajdach wcześniejsze pojedyncze przedmioty były pokazane w rozmaitych układach, na przykład cukierki leżały wśród rozrzuconych kredek, a kolorowe piłki - między kawałkami plasteliny. Wiesław Borowski, krytyk sztuki prowadzący Galerię Foksal, wspominał:

On [Boltanski] miał slajdy Les images stimuli, obrazki różnych zabawek, a ona fotografie z marami sennymi. To było skromne, taka nie wystawa, tylko obecność. Zdjęcia Annette były niby bezładnie rozrzucone po ścianach galerii. Pamiętam, że oboje byli bardzo rozradowani, wnosili dużo humoru i poczucia, że są u siebie. Przyjechał Stanisławski i wybrał kilka prac do muzeum. (Borowski 418, 429)

Pozornie inna pod względem formalnym była wystawa Boltanskiego z 1989 r. $^{8}$ Réserve nie składała się z fotografii (il. 3). Tym razem artysta wykorzystał podłogę galerii, na której rozłożył znoszone, zużyte ubrania. Zajmowały one całą jej przestrzeń. Poza ubraniami - i zawieszonymi na suficie sześcioma reflektorami - w galerii, czy raczej w „rezerwacie”, nic już nie było. Warszawska prezentacja była jedną z wersji tej wystawy. Na ową serię składają się między innymi: Réserve, Canada (1988), Réserve: la Fête de Pourim (Święto Purim, 1989); Réserve du Musée des enfants (Muzeum dla dzieci, 1989); Réserve: Lac des morts (Jezioro Umartych, 1990) ${ }^{9}$. W każdej z nich Boltanski używał nowego dla siebie „surowca” - ubrania. Leżały one bezładnie na podłodze albo były upchane na metalowych regałach, albo też zawieszone na gwoździach zapełniały ściany całego pomieszczenia. W realizacjach w Bazylei i w Paryżu ubrania funkcjonowały w zestawieniu z innymi charakterystycznymi dla artysty artefaktami. Boltanski pokazywał na przykład powiększone (i przez to zamazane) fotografie $\mathrm{z}$ twarzami dzieci lub umarłych. Tworzył z metalowych pudełek po herbatnikach swoiste archiwa, piedestały, półki, postumenty. Oświetlał to wszystko punktowo niewielkimi

\footnotetext{
${ }^{8}$ Christian Boltanski, Réserve, Galeria Foksal PSP w Warszawie, wystawa od 9 października $1989 \mathrm{r}$.

${ }^{9}$ Réserve, Canada, Ydessa Hendeles Art Foundation, Toronto, 1988; Réserve: la Fête de Pourim, Museum fur Gegenwartskunst, Bazylea, 1989; Réserve du Musée des enfants, Musée d'art moderne de la ville de Paris, 1989; Réserve, Centre Georges Pomidou, Paryż, 1990; Réserve: Lac des morts, Institute of Contemporary Arts, Nagoya, Japonia, 1990.
} 
lampami (czasem biurowymi), niekiedy wywołując przy tym zamierzone cienie. Cała ta wizualna oprawa, przytłaczająca masa różnokolorowych ubrań, a nawet zapach, który wydzielały w małej przestrzeni stare rzeczy - wszystko to miało oddziaływać na widza.

Ponad dekadę później Christian Boltanski ponownie pojawił się na Foksal. W 2001 r. w galerii miał miejsce pokaz C.B. sa vie, son œuvre (C.B. jego $\dot{z} y c i e$, jego praca). Ta skromna wystawa - bo przecież $\mathrm{w}$ przestrzeni warszawskiej galerii właściwie nic innego nie da się zrobić - była częścią większego projektu. Boltanski rozgościł się bowiem w Centrum Sztuki Współczesnej Zamek Ujazdowski w Warszawie z dużym retrospektywnym przeglądem swoich prac Revenir (Wrócić) (Boltanski. Revenir [bez stron]). Takie powiązanie nie powinno dziwić, zważywszy na osobę kuratorki Milady Ślizińskiej, która była związana zarówno z Foksalem (w latach 19721987), gdzie nie raz zastępowała Wiesława Borowskiego w prowadzeniu galerii, a znając świetnie język angielski, wniosła istotny wkład w kontakty zagraniczne (Borowski 418, 244, 327, 357, 408), jak i z CSW (1990-2011), będąc tam Głównym Kuratorem Programu Wystaw Międzynarodowych. Na Zamku artysta pokazał wówczas swoje wcześniejsze dzieła (jak Monument, 1986; Les Images Noires, 1996; Théâtre d'Ombres, 1989; Réserve: Les Suisses Morts, 1990) oraz pracę przygotowaną specjalnie na tę wystawę Les Habitants de Varsovie (Mieszkańcy Warszawy, 2001) ${ }^{10}$. Projekt obejmował również działania poza murami CSW. Na ścianach budynków i ulicach Warszawy pojawiło się 40 billboardów, na których można było zobaczyć parę powiększonych oczu, prawdopodobnie żydowskiego dziecka, symbolicznie wypatrujących śladów po historii i zagładzie żydowskich mieszkańców miasta (Witness / Świadek, 2001). Co jeszcze bardziej znamienne, dzień przed otwarciem obu wystaw Boltanski umieścił w stołecznym wydaniu $\mathrm{Ga}$ zety Wyborczej wkładkę (w nakładzie 5 tys. egzemplarzy) z powiększonym zdjęciem drużyny młodych żydowskich bokserów z klubu „Gwiazda”. Prosił

\footnotetext{
${ }^{10}$ Można w tym miejscu przywołać słowa Grzegorza Kowalskiego, który z okazji laudacji doktoratu honoris causa dla Christiana Boltanskiego, nadanego przez ASP w Poznaniu, tak oto wypowiedział się o wystawie w warszawskim CSW: „Boltanski pokazał szerokie spektrum swych prac, dawnych i nowych. Można było prześledzić ewolucję jego twórczości, spojrzeć z pewnym dystansem na całokształt. To była wielka wystawa. Miałem wrażenie, że jest aktem ekshibicjonistycznej odwagi artysty. Boltanski pokazał, jakim jest. Do tej wystawy odnieść chciałem swój postulat o wykrystalizowanie jednoznacznego przesłania - to była wystawa o śmierci z bezwzględnie pesymistycznym przesłaniem, które streszczę: na nic nasze życie pełne trudu, wizji i wyrzeczeń, aby te wizje zrealizować. Przychodzi nam umrzeć i zostają po nas tylko nietrwałe ślady. Bez czucia i życia” (Kowalski 182-183).
} 
czytelników o kontakt, gdyby udało się rozpoznać którąkolwiek ze sfotografowanych osób, bo przecież ci ludzie żyli w Warszawie w 1937 r. O ile w CSW, jak oceniał Adam Mazur, można było obejrzeć coś w rodzaju przeglądu prac artysty (a w pamięci pozostają dziesiątki portretów, pojedynczych i grupowych, ściany pokryte używanymi ubraniami oraz niesamowite oświetlenie, nadające całości nieomalże sakralny charakter), to Galeria Foksal została zamieniona w muzeum eksponatów dokumentujących życie Boltanskiego (Mazur, Oświetlenie). W ramach tej kameralnej propozycji artysta przygotował między innymi tekst, odtwarzany i puszczany przez głośniki w sali wystawowej - w stu zdaniach różne osoby opisywały Boltanskiego po śmierci. Były to, oczywiście, wyobrażenia artysty o tym, jak może być wspominany. „Jedna historia jednego człowieka, któremu przypadło urodzić się w 1944 roku, nazywać się Boltanski, być artystą, którego wypełniają niepokoje, codzienne troski, poczucie humoru i ustawiczne zmaganie się z pamięcią, pamiętaniem, pamiątkami..." - komentowała Eleonora Jedlińska (Biografia, 76). Nietrudno zgadnąć, że sporo z tego, co pojawiło się na wystawie, było swego rodzaju mistyfikacją.

W 2008 r. francuski twórca ponownie pojawił się w Warszawie, by po raz czwarty przygotować wystawę w Galerii Foksal. W niewielkiej przestrzeni galerii zaprezentował instalację Le Cœur / Serce, której towarzyszył performance Póki my żyjemy..., zrealizowany dwa dni po otwarciu wystawy w tzw. Reducie Banku Polskiego ${ }^{11}$. „Sercem” (istotą) instalacji jest sprzężenie dźwięku i światła, nakładanie się ich na siebie, w rytmie, który wyznacza bicie serca Christiana Boltanskiego. Pomieszczenie galerii jest pomalowane na czarno, jedyne światło daje słaba żarówka, która zapala się i gaśnie, jej migotanie jest powiązane z pulsującym, przeszywającym dźwiękiem (il. 4). Czy to swoisty autoportret artysty, który twierdził, że jego serce bije za szybko i że - mimo że jest chore - to przeżyje go, gdy on umrze. „Gdzieś będzie biło" (cyt. za: Franke 27). Takie odczytanie sugerują czarno-białe portrety artysty, wyświetlane w czarnym korytarzu na białej zasłonie. Ogromne twarze Boltan-

${ }^{11}$ Wystawa Le Cæur / Serce w Galerii Foksal miała miejsce w dniach 22 lutego - 11 kwietnia 2008 r. Towarzyszący jej performance Póki my żyjemy... został przeprowadzony dwa dni po otwarciu wystawy w tzw. Reducie Bank Polski (ul. Bielańska 10). Nazwa budynku odnosi się do faktu, że był on przedwojenną siedzibę Banku Polskiego, a w czasie powstania warszawskiego stanowił ważny strategicznie bastion powstańczy. Instalacja Serce po raz pierwszy była prezentowana na wystawie Christian Boltanski. Prendre la parole w Marian Goodman Gallery w Paryżu (2005), a następnie pojawiła się na kolejnych pokazach: Ultime Notizie. Christian Boltanski, w PAC Padiglione d'Arte Contemporanea w Mediolanie (2005), Zeit/Time, w Institut Mathildenhöhe w Darmstadt (2006), Herzschlag w Pfefferberg Berlin w Berlinie (2007). 
skiego, w różnym wieku - dziecka, młodzieńca, mężczyzny, zapętlają się przed widzem w nieustannym procesie przenikania, zmiany i ponowienia, od początku do końca, i tak raz za razem.

Zaprezentowany poza przestrzenią galerii spektakl Póki my żyjemy... był wspólnym dziełem polsko-francuskiej grupy artystów. Poza Boltanskim, współtworzyli go i uczestniczyli w nim: Angelika Markul (artystka, uczennica Boltanskiego), Jean Kalman (scenograf), Franck Krawczyk (kompozytor) oraz wolontariusze. Czterogodzinna akcja rozgrywała się na pograniczu jawy, wyobraźni i snu. Poszczególne sekwencje spektaklu - niełączące się w logiczną całość - były powtarzane, widzowie mogli zatem uczestniczyć w dowolnej części widowiska. Jedno z pomieszczeń, ogrodzone folią, wypełniała gęsta mgła, przeszywana oślepiającym światłem reflektora, przez co można było zobaczyć jedynie czarną sylwetkę harmonisty, siedzącego na krześle ustawionym na podium na środku sali (il.5). Muzyka harmonii i zanikający śpiew kobiecy dochodziły jakby z oddali. W innej części aktorzy ubrani w długie do ziemi płaszcze i skryci za maskami zwierząt, przechadzali się z latarkami wśród publiczności. Ponownie ciemne wnętrze, mgła i dźwięki kołatki, fletu, ujadających psów i męskiego głosu śpiewającego znaną, legionową Szara piechote, stanowiącą przecież ważny element kantorowskiego spektaklu Wielopole, Wielopole (premiera w 1980 r. we Florencji). Performance odwoływał się zatem do przeszukiwania pamięci i wywoływania wspomnień, a także w bezpośrednim odniesieniu do Tadeusza Kantora, artysty niezwykle ważnego i dla Galerii Foksal, i dla samego Boltanskiego (Jedlińska, Biografia 77) ${ }^{12}$.

\section{CZTERY WYSTAWY, TRZY TEMATY, JEDNA METODA?}

Pierwszą i ostatnią (jak dotąd) wystawę Christiana Boltanskiego w Galerii Foksal dzieli równo 30 lat. Przez ten długi czas zmieniał się sam artysta, zmieniała się galeria. Do ich wzajemnych spotkań dochodziło w różnych - zarówno dla niego, jak i dla niej - epokach. Druga połowa lat 70. to był okres, w którym Foksal dochodził - jeśli można użyć takiego stwierdzenia do swojego szczytu, co szczególnie widoczne było na arenie międzynarodowej. To wtedy w Warszawie pojawili się tacy artyści, jak między innymi grupa Art\&Language, Arnulf Rainer, John Hilliard, Lawrence Weiner,

\footnotetext{
${ }^{12}$ Por. opis performance na stronie Galerii Foksal („Póki my żyjemy...”).
} 
Michael Craig-Martin. Zaraz po tym, na przełomie lat 70. i 80., Galeria Foksal odbyła swoiste tournée po Wyspach Brytyjskich, prezentując swój teoretyczny dorobek i dokumentację działalności (w tym w Institute of Contemporary Arts w Londynie). Boltanski znajdował się wówczas jeszcze w pierwszym prawdziwie twórczym okresie. W wieku 23 lat zrozumiał, że nie jest dzieckiem, jak o tym sam opowiadał („Polański tak, Uklański nie!” 48-49). Będąc w Musée de l'Homme (Muzeum Człowieka) w Paryżu, podziwiał przedmioty ,zaklęte” w gablotach, z pożółkłymi fotografiami ludzi sprzed lat, zapewne już nieżyjących. Każda gablota przedstawiała świat, którego już nie było, i świadomość tego faktu, stała się dlań katalizatorem zmiany, a tym samym rozwoju. Les images stimuli z 1978 r. można w tym kontekście uznać za „dojrzały” produkt podejmowanych od dekady prób i eksperymentów z fotografią, przedmiotami znalezionymi, reprezentacjami świata jego dzieciństwa.

Koniec lat 80. stanowiło $\mathrm{z}$ kolei dla warszawskiej galerii zarówno nowe otwarcie, jak i zarazem pewne zamknięcie. Otwarcie - gdyż po trzyletniej przerwie w funkcjonowaniu spowodowanej stanem wojennym istniało zagrożenie przejęcia lokalu przez inną instytucję. Galeria ponownie wystartowała, na fali wsparcia artystów zapoczątkowaną zbiorową wystawą $\mathrm{w}$ obronie placówki, i ponownie przyciągnęła kolejne znane międzynarodowe nazwiska. Zamknięcie - zbliżał się koniec epoki PRL-u, kończyć się też miał patronat potężnych w tamtym czasie Pracowni Sztuk Plastycznych. Galeria, jak i cały kraj, stały przed wielką niewiadomą, a wszystko bardzo szybko się zmieniało. Boltański, ponad 40-letni artysta, chwilę wcześnie wszedł w swój drugi ważny okres twórczy. Zmarli jego rodzice, a on sam czul, że musi na dobre skonfrontować się z tematem Zagłady. Widmo to wisiało nad nim od chwili narodzin. Opowiadał w wywiadzie:

W moim przypadku traumą jest data urodzenia: wrzesień 1944 roku. Czuję się więc jak rozbitek, ocaleniec z tej wielkiej katastrofy - II wojny światowej i Holocaustu. Tata pochodził z rodziny odesskich Żydów, mama była katoliczką z Korsyki. Nie wiem, dlaczego nie zrobili aborcji - gdyby byli rozsądni, powinni byli się na to zdecydować. Kołysanką mego dzieciństwa były opowieści o Shoa. Prędko zacząłem zadawać sobie pytania na temat dobra i zła. („Polański tak, Uklański - nie!” 46)

Sztuka Boltanskiego z tego okresu to właśnie stawianie pytań, czego przykładem jest dramatyczna seria Réserve (z warszawską odsłoną z 1989 r.). Ponad dekadę później artysta spinał ten czas wystawą Revenir, wychodząc 
poza mury Zamku Ujazdowskiego i trafiając ponownie na Foksal. Galeria nie miała możliwości, by przygotować dużą wystawę o charakterze retrospektywnym, ale miała je Milada Ślizińska, współpracowniczka Borowskiego, odpowiedzialna teraz za program międzynarodowy w reprezentatywnym stołecznym Centrum Sztuki Współczesnej. W obu wystawach Boltanski rozliczał jakby miniony czas i wprost pytał mieszkańców Warszawy, co zrobili ze swoimi Żydami.

Następna wystawa, z 2008 r., miała już nieco inny wydźwięk. Oczywiście nadal dominowały wątki autobiograficzne (czy też pseudobiograficzne), ale przybierały one nową barwę - odniesienia do starości. Boltanski tłumaczył, że ostatni okres datuje od 2004 r., czyli od momentu kiedy wkracza w starość (60 lat) („Polański tak, Uklański - nie!” 49). W poważny, dostojny wręcz wiek weszła również galeria - nieczęsto zdarza się, by taka placówka funkcjonowała ponad cztery dekady. W jej przypadku zmieniło się wszystko. $\mathrm{Na}$ emeryturę odszedł Wiesław Borowski (2006), pozostawiając galerię pod kierownictwem najpierw Jaromira Jedlińskiego, a następnie Katarzyny Krysiak. Pojawiło się kolejne pokolenie pracowników, a „stara gwardia" artystów powoli odchodzi. Status galerii już nie jest taki sam. Jest jedną z wielu, i choć nadal znajduje się w samym centrum Warszawy, w tej samej oficynie Pałacu Zamoyskich, to pod względem prestiżu, wpływu na świat rodzimej sztuki sytuuje się raczej na swoistym marginesie. Nowy zespół galerii niewątpliwe mierzy się nieustannie z, być może, przytłaczającą legendą galerii. Są jednak artyści, jak właśnie na przykład Christian Boltanski, którzy nadal dostrzegają „,aurę” tego miejsca. Niewykluczone, że proponowane przez nie warunki idealnie korespondują z ideami francuskiego twórcy. Może więc w ciemnej przestrzeni galerii w 2008 r. pulsowało nie tylko serce artysty?

Tak dokonanemu rozpoznaniu tematów należy się teraz przyjrzeć szczegółowo. Na zrealizowanych na Foksal czterech wystawach można odnaleźć trzy tematy: dzieciństwo, Zagładę, starość. Jak w tym kontekście rozumieć ową jedną metodę?

Pierwszą, narzucającą się wręcz wskazówką może być przyjęcie założenia, że dla artysty najważniejszy jest czas czy raczej, by określić to precyzyjniej, jego utrata, a zatem przemijalność. I wówczas na myśl przychodzi fotografia. Dlaczego? Boltanski chętnie posługuje się techniką gromadzenia fragmentów rzeczywistości, rozumianych jako świadectwa ludzi (żyjących albo zmarłych), a następnie wykorzystuje je w sztuce. W Les images stimuli są to pozornie jego własne „świadectwa” czy też obecności, jak widział to Wiesław Borowski. Artysta przywołuje poprzez zdjęcia przedmiotów i dzieci 
wspomnienia $\mathrm{z}$ dzieciństwa (czyli typowe tematy z rodzinnych albumów), ale nie jest ono tylko jego dzieciństwem. Jak wyjaśnia $w$ jednym $z$ wywiadów, uważa że „sztuka funkcjonuje jako rodzaj symulacji i że każdy po tej symulacji tworzy pewien rodzaj wizji własnej przeszłości" (Claverie $)^{13}$. Tłumaczy to następnie na przykładzie zdjęcia dziecka biegnącego po plaży - dla każdej osoby oglądającej to zdjęcie będzie to inne dziecko na innej plaży. Inaczej mówiąc, osoba lub przedmiot, umieszczony w galerii, muzeum (czy po prostu w witrynie), będzie odczytany i zrozumiany przez każdego na inny, jego własny sposób, co sprawi, że staną się osobą lub przedmiotem z jego własnej przeszłości. Dzieje się tak dzięki fotografii, która ten proces stymuluje. Francuski twórca w swojej sztuce stara się nadać sens każdej chwili, która przemija.

Każdy nosi w sobie martwe dziecko i każda chwila jest chwilą przemijającą, chwilą martwą, którą pamięć próbuje ocalić, wiedząc, że jest to beznadziejna walka. Wszystko się rozpływa, nawet z takimi środkami technicznymi jak fotografia, jest ona bardzo związana z ideą śmierci, jako że to co jest jej bliskie, to właśnie pragnienie uchwycenia chwili, która umiera w jednym momencie. W pewien sposób chwila nie jest już żywa, jest schwytana. (Claverie)

Można to uznać za kwintesencję myślenia o sztuce Christiana Boltanskiego, przy czym jest on w tym niezwykle podobny do Tadeusza Kantora. Należy w tym miejscu przypomnieć, że pierwszą inspiracją do takiego postrzegania rzeczywistości był wpływ paryskiego Muzeum Człowieka. Ono go w swoisty sposób naznaczyło. Pierwsza wystawa w Galerii Foksal bezpośrednio nawiązywała do wcześniejszej pracy Vitrines de Reference (1971) (Galeria Foksal 1966-1994 124) ${ }^{14}$. Artysta w swoich gablotach zachował własne zdjęcia, włosy, fragmenty ubrań, próbkę pisma i inne podobnego rodzaju rzeczy osobiste. W tym ujęciu wyglądały one niczym relikwie lub archeologiczne pozostałości zaginionych cywilizacji. Było to swoiste zamrożenie

${ }^{13}$ Christian Boltanski jest jednym z tych artystów, którzy w swojej praktyce sięgają po obraz, i to on, a nie świat, służy im często za punkt odniesienia. Boltanski czyni tak właściwie od tego momentu, kiedy sięgnął po fotografię, i włączył zdjęcia rodzinne i skarby dzieciństwa w swoje prace (Rouillé 166).

${ }^{14}$ Warto to zestawić z praktyką Kantora. Katarzyna Fazan, pochylając się na zdjęciami $\mathrm{z}$ archiwum Tadeusza Kantora, reprezentującymi jego teatr i poświadczającego istnienie osoby, konfrontuje je z jednej strony z jego skłonnością do paradoksów i sprzeczności, z drugiej - do idei gromadzenia, przechowywania i odsłaniania dokumentacji. Dowodzi, że fascynuje go idea uczynienia z dokumentacji dzieła sztuki przy zachowaniu, a właściwie wykreowaniu roboczej funkcji reprezentacji. Autorka analizuje przy tym kreacyjny sens fotografii portretowych Kantora (Fazan 419-441, 445-460). 
„skrawków życia”, a sam Boltanski jawi się tu jako antropolog-fotograf, proponujący siebie jako przedmiot badań. Ale w jego wydaniu, rzeczywistość łączy się niezmiernie z fikcją. Nigdy nie ma pewności ani gwarancji, że pokazywane sekwencje są autentyczne (Olek 165) ${ }^{15}$. Wykorzystuje zatem fakt, że „fotografia przyciąga, ponieważ wywołuje resentymenty jako «prawdziwa», opowiada autentyczną historię, daje złudzenie rzeczywistości i niemal zawsze towarzyszy jej jakaś legenda, która się identyfikuje z obrazem" (Jedlińska, Sztuka po Holokauście 165).

Artysta równie często sięga po nieartystyczne z pozoru obiekty, jakimi są amatorskie fotografie anonimowych osób. Tak dzieje się w serii Le Club Mickey, w której poszczególne fotografie zespala z sobą wspólny temat dzieciństwa. I w przedziwny sposób, wówczas gdy pokazuje wielką ilość portretów w różnych układach, anonimowość - jak zauważa Jan Dibbets - nabiera osobowości. Ten holenderski konceptualista, specjalizujący się użyciu fotografii, postrzega Boltanskiego wręcz jako jej pioniera. „Jego pionierskość dotyczy wielowarstwowości emocjonalnej, jaką uzyskuje w swoich pracach bez rozciągania duszy fotografii" i w ponownym użyciu materiału już istniejącego (gotowych zdjęć) - w różnych układach, często tych samych, poddanych jedynie manipulacji technicznej (Dibbets 167). A przecież trzeba pamiętać, że w odróżnieniu od innych artystów uprawiających fotografię on fotografii po prostu używa, nie tworzy jej. Sam Boltanski nie określa się jako fotograf, widzi siebie jako malarza, które stosuje inne media właśnie w zgodzie z malarską tradycją ${ }^{16}$.

Co jednak najbardziej w tym wszystkim istotne, to podejście francuskiego artysty do samego medium fotografii. Jego praktyka artystyczna wyraźnie pokazuje, że oznacza ona dla niego „zamrożenie” czy raczej uśmiercenie chwili. Nie sposób nie powiązać tego z rozważaniami André Bazina, który w Ontologii obrazu fotograficznego zaproponował koncepcję mumifikacji rzeczywistości (Bazin 422-426). Oznacza to, że fotografia artystyczna nie tworzy rzeczywistości artystycznej, jak czyni to sztuka. Dzieje się coś innego - „balsamuje” czas, ratując go przez samozniszczeniem. „Istotą fotografii staje się potwierdzenie faktu «to było», a zatem w fotografiach chodzi o czas, a nie o formę, ponieważ najważniejszą kwestią jest, że stanowią one dla nas klisze pamięci” (Tomaszczuk 33). Bazin dowodził, że to właściwie tęsknota za nieśmiertelnością, wynikająca ze strachu przed rozkładem fizycz-

\footnotetext{
${ }^{15}$ Por. Smith 634-657.

${ }^{16}$ Boltanski nie raz twierdził, że „maluje z użyciem fotografii”. Por. Rouillé 331, 390-391; Morgan 49.
} 
nego ciała i unicestwieniem materii, świadomość kruchości życia i niepewność co do przyszłości, stały za potrzebą zostawienia śladu po sobie. Fotografia bez wątpienia myślenie to prowokuje bardziej niż inne obrazy. Pisal o tym również Roland Barthes:

Albowiem nieruchomość zdjęcia stanowi jakby rezultat przewrotnego pomieszania dwu pojęć: Rzeczywistego i Żyjącego. Poświadczając, że przedmiot był realny, zdjęcie każe podstępnie uwierzyć, że jest on żywy. Dzieje się to z powodu właśnie tej przynęty, która przypisuje realności, absolutnie wyższą wartość, jakby wieczną. Ale przenosząc tę rzeczywistość ku przeszłości „to-co-było”, sugeruje, że jest ona już martwa. (Barthes 141$)^{17}$

To przekonanie jest niekiedy wyjątkowo silne, można wręcz wtedy zapomnieć, że fotografia - jako fascynujący obraz rzeczywistości - jest jedynie ułudą, a nie „naturalnym zjawiskiem”. Boltanski w swoim działaniu wyciąga konkretne wnioski z tego faktu.

\section{MAŁE PAMIĘCI - RELIKWIE}

Niewątpliwie Christian Boltanski, tak jak wspomniany wyżej André Bazin, odwołuje się do psychologii relikwii wynikającej z „kompleksu mumii”. Dzięki fotografii tworzy on kolejne albumy fotograficzne (jak Rodzinny album państwa D. od 1939-1964, 1971) lub inwentarze rzeczy drobnych (Spis przedmiotów, które należały do pewnej kobiety z Baden-Baden, 1973). Artysta przechodzi $\mathrm{w}$ ten sposób od zainteresowania rzeczami zwykłymi i obrazami kultury masowej (które jeszcze widać w Les images stimuli, 1978) do małych, lokalnych narracji. Francuski twórca skupia się w nich na przywoływanej przez siebie kategorii „małej pamięci emocjonalnej”, która jest bezpośrednio związana $\mathrm{z}$ danym człowiekiem, jego indywidualnym bytem, który nieczęsto jest konfrontowany z „dużą pamięcią” zawartą w his-

${ }^{17}$ Barthes postrzega fotografię nie tylko jako śmierć. Jest ona dla niego również pamięcią, a więc przywołaniem czasu umarłego (zatrzymanego) i na nowo przeżywanego. Równie, a może jeszcze bardziej pesymistyczną wizję rozsnuwa inna klasyk teorii fotografii, Susan Sontag, przekonując, „robiąc zdjęcie stykamy się ze śmiertelnością, kruchością, przemijalnością innej osoby lub rzeczy. Właśnie dlatego, że wybieramy jakąś chwilę, wykrawamy ją i zamrażamy, wszystkie zdjęcia stanowią świadectwo nieubłagalnego przemijania”. Dzieje się nawet więcej. Już sam fakt naciśnięcia spustu migawki jest dla niego swego rodzaju morderstwem, jego sublimacją. „Robić ludziom zdjęcia to gwałcić ich - oglądać takimi jakimi nigdy sami siebie nie widują, zyskać o nich wiedzę. jakiej sami nigdy nie będą mieli i w ten sposób uczynić z nich przedmioty, którymi można symbolicznie zawładnąć" (Sontag 22-23). Por. Ferenc 107-122; Belting 174, 223. 
torii i książkach. Według niego wraz ze śmiercią następuje utrata tożsamości, wsparta zapominaniem. Jak dowodzi Adam Mazur, rolą artysty jest zatem podjęcie wysiłku wydobycia zmarłych z zapomnienia, wysiłku przywrócenia im $\mathrm{z}$ powrotem tożsamości (Mazur, „Wstęp”) - i to właśnie w swoich pracach czyni Boltanski. Reservé, projekt bilbordowy do wystawy Revenir, czy też C.B. sa vie, son æuvre, są tego najlepszym przykładem. W każdym z tych przypadków - bez względu, czy tworzą ją zdjęcia, czy ubrania - to system formalny Boltanskiego jest prosty i ascetyczny (bo przecież sam nazywa się minimalistą, który nie ucieka od uczuć). Fotografia i rzecz-przedmiot, wspomnienie i jego pozorna materializacja - to wszystko składa się na sztukę francuskiego artysty. Boltanski bowiem bawi się impulsem zachowania i upublicznienia tego, co kiedyś było osobiste i prywatne, i w tym kontekście porzucone (lub „skonfiskowane”) ubrania i zdjęcia są tego najwyższym wyrazem (Bergman-Carton 3). Owe ludzkie artefakty stanowią prawie to samo, co martwe ciało: ktoś był, a teraz go nie ma. Stawiając swoje pytania, artysta ujawnia, jak ważna w jego praktyce jest dwoistość między nieobecnością a obecnością. To wyraźnie pokazuje, że Boltanski, malarz-fotograf, nie tylko wykorzystał materię fotografii jako swój surowiec podstawowy, ale podąża od lat o wiele dalej: całe jego dzieło jest skonstruowane wokół paradygmatu fotografii postrzeganej w ujęciu André Bazina. Jest zatem i relikwią, i pamięcią.

Owładnięty czasem minionym i śmiercią świat Boltanskiego jest pozbawiony konsystencji. Zbyt nostalgiczne, aby mogło być realistyczne, dzieło to, łączące przyszłość ze śmiercią i uznające jednocześnie całość za sumę odrębnych jednostek, odrzuca wszelką uniwersalną perspektywę, jakikolwiek projekt na przyszłość oraz wszelkie cele, o których myśleli współcześni: „Zawsze jest jeden plus jeden. Kumulowanie małych pamięci”. (Rouillé 426-427) ${ }^{18}$

Nie sposób nie zgodzić się tu z André Rouillé. To wierny opis świata obrazów Christiana Boltanskiego.

\footnotetext{
${ }^{18}$ Przywołane na końcu słowa - kumulowanie małych pamięci - pochodzą z wywiadu z artystą (,What Is Erased” 1).
} 


\section{BIBLIOGRAFIA}

Bazin, André. Ontologia obrazu fotograficznego. Fotospoleczeństwo. Antologia tekstów z socjologii wizualnej, red. Małgorzata Bogunia-Borowska i Piotr Sztompka, Wydawnictwo Znak, 2012, ss. $422-426$.

Barthes, Roland. Światto obrazu. Uwagi o fotografii. Tłum. Jacek Trznadel, Wydawnictwo Aletheia, 2008.

Belting, Hans. Antropologia obrazu. Szkice do nauki o obrazie. Tłum. Mariusz Bryl, Universitas, 2007.

Bergman-Carton, Janis. „Christian Boltanski's Dernières Années: The History of Violence and the Violence of History". History and Memory, t. 13, nr. 1, 2001, ss. 3-18.

Boltanski. Revenir, red. Milada Ślizińska, Centrum Sztuki Współczesnej Zamek Ujazdowski 2003.

Borowski, Wiesław. Zakrywam to, co niewidoczne. Wywiad-rzeka. Rozmawiaja Adam Mazur i Ewa Toniak. Wydawnictwo Stowarzyszenie 40000 Malarzy, 2014.

Claverie, Jana. Entretien de Christian Boltanski avec Jana Claverie. Christian Boltanski: Leçon de ténèbres, kat. wyst., Belvédère et Jeu de Paume du Jardin Royal du Château de Prague, Prague Institut Français, Praga 1994 [na podstawie wersji roboczej thumaczenia dostępnej w Archiwum Galerii Foksal].

Christian Boltanski. Kronika wypadków 1973 [folder, tekst Carolle Naggar]. Wydawnictwo B.W.A. Lublin, 1978.

„Dialog”. Moderna Museet, Stockholm 7 september-20 oktober 1985

Dibbets, Jan. [bez tytułu ], Zeszyty Artystyczne, nr 19, 2010, ss. 167-170.

Fazan, Katarzyna. Kantor. Nie/Obecność. Wydawnictwo Uniwersytetu Jagiellońskiego, 2019.

Ferenc, Tomasz. „Fotografia i śmierć - uwikłanie i realna styczność”. Dyskurs: Pismo NaukowoArtystyczne ASP we Wroctawiu, nr 24, 2017, ss. 107-122.

Franke, Melanie. „Zu viel Pathos (trial and error). Christian Boltanski im Pfefferberg”, von hundert, 004/100, nr 11, 2007, s. 27.

Galeria Foksal 1966-1994, red. Wiesław Borowski, Małgorzata Jurkiewicz i Andrzej Przywara, Galeria Foksal SBWA.

Jedlińska, Eleonora. Sztuka po Holocauście. Biblioteka Tygla Kultury, 2001.

Jedlińska, Eleonora. „Biografia/«Auto-biografia» - Pamięć/Śmierć/Życie”. Format. Pismo Artystyczne, $\mathrm{nr}$ 54, 4/2007/2008, ss. 72-77.

Kowalski, Grzegorz. [bez tytułu], Zeszyty Artystyczne, nr 19, 2010, ss. 179-183.

Kuc, Monika. „Zaczęło się od niemego mysza”, Rzeczpospolita, 25.04.2008, www.rp.pl/artykul/ 125563-Zaczelo-sie-od-niemego-mysza.html. Dostęp 29.09.2020.

Morgan, Stuart. „Little Christians. Christian Boltanski in conversation with Stuart Morgan”. Artscribe International, November/December, 1988, ss. 46-49.

Mazur, Adam. „Oświetlenie śmierci”, fototapeta, 2001, fototapeta.art.p1/2001/blt.php. Dostęp 29. 09.2020.

Mazur, Adam. „Wstęp”. Boltanski. Revenir, red. Milada Ślizińska, Centrum Sztuki Współczesnej Zamek Ujazdowski, 2003.

Millet, Catharine. „Boltanski et Le Gac”. Les Lettres françaises, ${ }^{\text {er }}$ avril 1970, s. 26.

Olek, Jerzy. „Niejednoznaczność oczywistości”. Zeszyty Artystyczne, nr 19, 2010, ss. 159-166. 
„Polański tak, Uklański - nie! Z Christianem Boltanskim rozmawia Jacek Tomczuk”. Przekrój, nr 7, 2011 [15.02], ss. 46-49.

„Póki my żyjemy...”, Galeria Foksal, www.galeriafoksal.pl/poki-my-zyjemy. Dostęp 29.09.2020.

Rouillé, André. Fotografia. Między dokumentem a sztuka wspótczesną. Tłum. Oskar Hedemann, Universitas, 2007.

Smith, Olga. „Authorless Pictures. Authorless Pictures. Uses of Photography in Christian Boltanski's Early Work (1969-1975)". Art History: Journal of the Association of Art Historians, t. 40, nr 3, 2017, ss. 634-657.

Sontag, Susan. O fotografii. Tłum. Sławomir Magala, Wydawnictwo Karakter, 2009.

Tomaszczuk, Zbigniew. „Fotografia rzeczywistości - rzeczywistość fotograficzna”. Prace Naukowe Akademii im. Jana Dlugosza w Częstochowie, seria: Edukacja Plastyczna, z. 6, 2011, ss. 25-35.

„What Is Erased, a conversation between John Baldessari and Christian Boltanski”. Blind Spot Photography, nr 3, 1994, ss. 1-4.

Zaranek, Łukasz. „Mysz, która podbiła świat. Miki kończy 90 lat, , tvp info, 18.11.2018, www.tvp.info/40003985/mysz-ktora-podbila-swiat-miki-konczy-90-lat. Dostęp 29.09.2020.

\section{KUMULOWANIE MAŁYCH PAMIĘCI. \\ ŚWIAT OBRAZÓW CHRSTIANA BOLTANSKIEGO W GALERII FOKSAL}

Streszczenie

Artykuł jest próbą spojrzenia na praktyki artystyczne Christiana Boltanskiego. Szczególną uwagę poświęcono czterem jego wystawom, jakie odbyły się w warszawskiej Galerii Foksal. Pokazują one, że francuski artysta sięga po medium fotografii i stosuje je w swojej sztuce w specyficznym ujęciu nadanym przez André Bazina. Oznacza to, iż fotografia jest dla Botlanskiego narzędziem mumifikacji rzeczywistości, która staje się zarazem i relikwią, i pamięcią.

Słowa kluczowe: Christian Boltanski; pamięć; sztuka jako fotografia; vanitas; mikrohistorie.

\section{ACCUMULATING LITTLE MEMORIES: CHRISTIAN BOLTANSKI'S WORLD OF IMAGES IN THE FOKSAL GALLERY}

\section{Sum mary}

This article is an attempt to look at the artistic practices of Christian Boltanski. Particular emphasis is placed on four of his exhibitions which were held at the Foksal Gallery in Warsaw. They show that the French artist not only uses the medium of photography in his art, but uses it in the specific approach as designated by André Bazin. This means that, for Boltanski, photography is a tool for the mummification of reality, which then becomes both a relic and a memory.

Keywords: Christian Boltanski; memory; art as photography; vanitas; micro-stories. 


\section{Christian Boltanski Annette Messager}
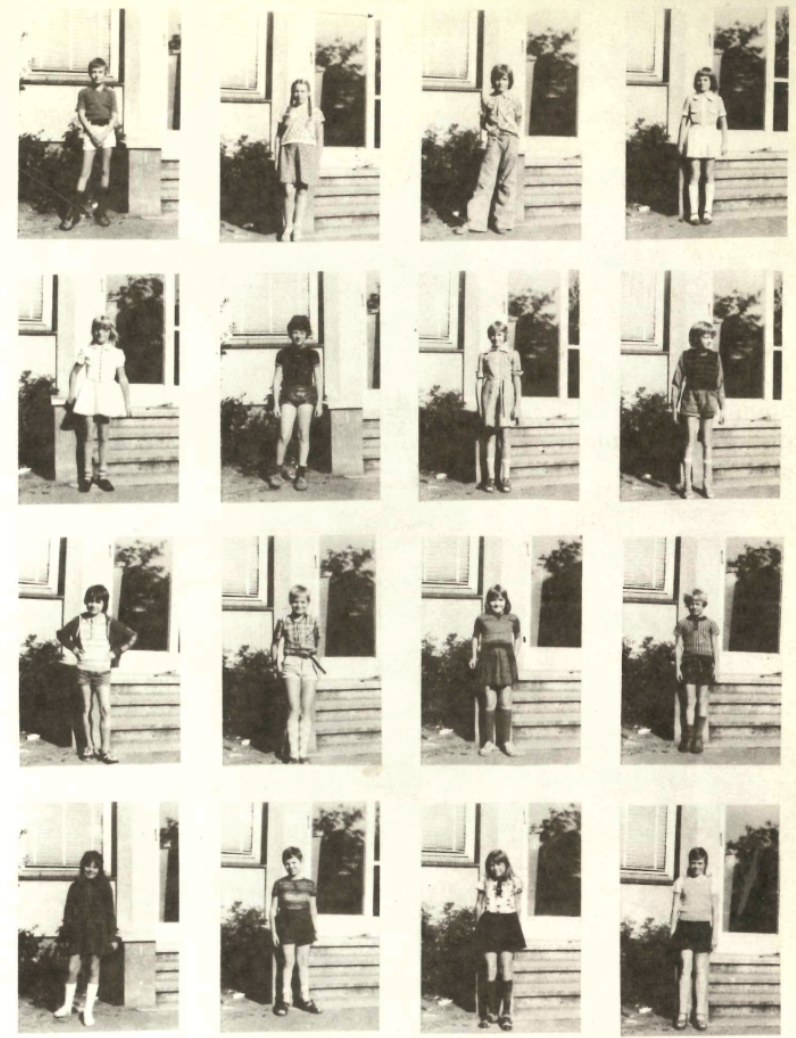

Christian Boltanski, 1977

1. Christian Boltanski, Reserve, Galeria Foksal, Warszawa, 1989, za: Christian Boltanski. Reserve, kat. wyst., Galeria Foksal, Warszawa 1989 

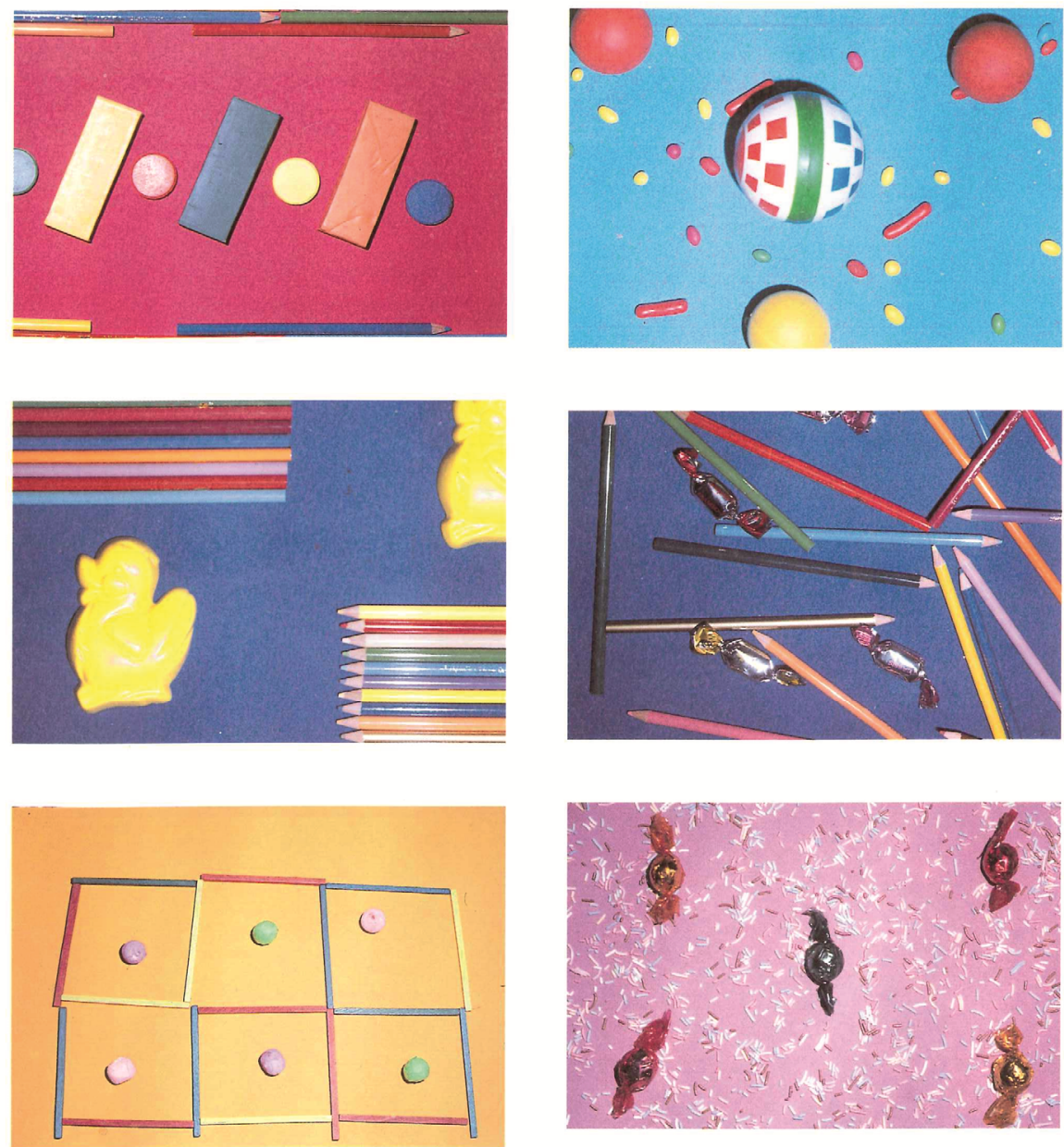

2. Christian Boltanski, Les images stimuli, 1978,

za: Galeria Foksal 1966-1994, red. W. Borowski, M. Jurkiewicz, A. Przywara, Galeria Foksal SBWA, 1994, s. 68 


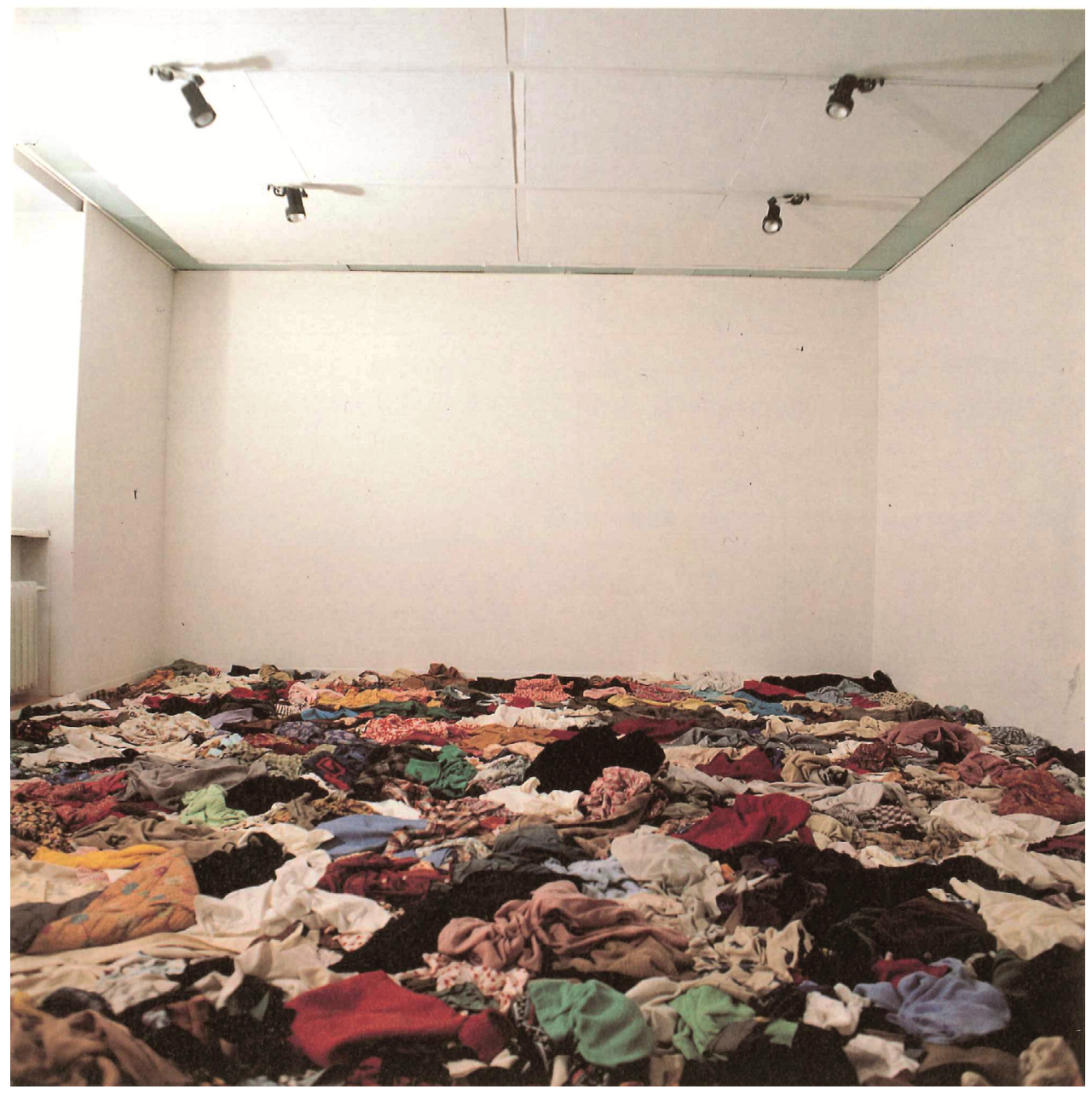

3. Christian Boltanski, 1977,

za: Galeria Foksal 1966-1988, red. W. Borowski, M. Jurkiewicz, A. Przywara, Galeria Foksal SBWA, 1989. 


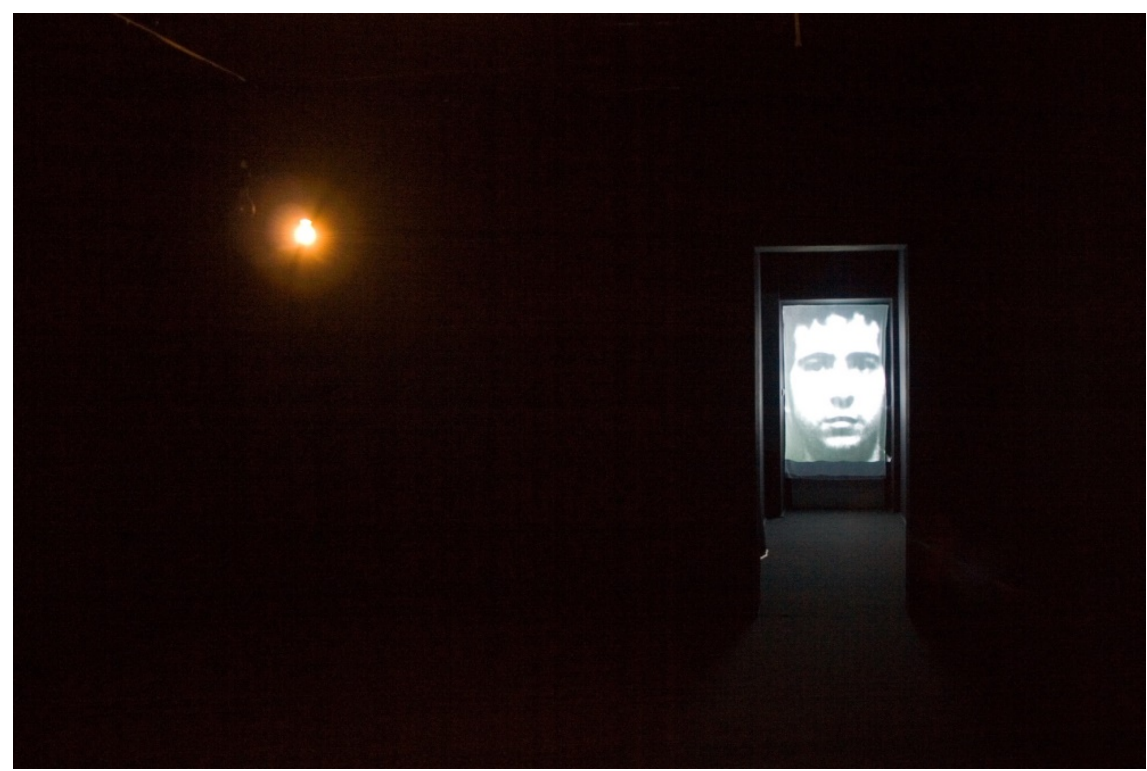

4. Christian Boltanski, Serce, Galeria Foksal, Warszawa, 2008. Fot. Jerzy Gładykowski. Dzięki uprzejmości Galerii Foksal

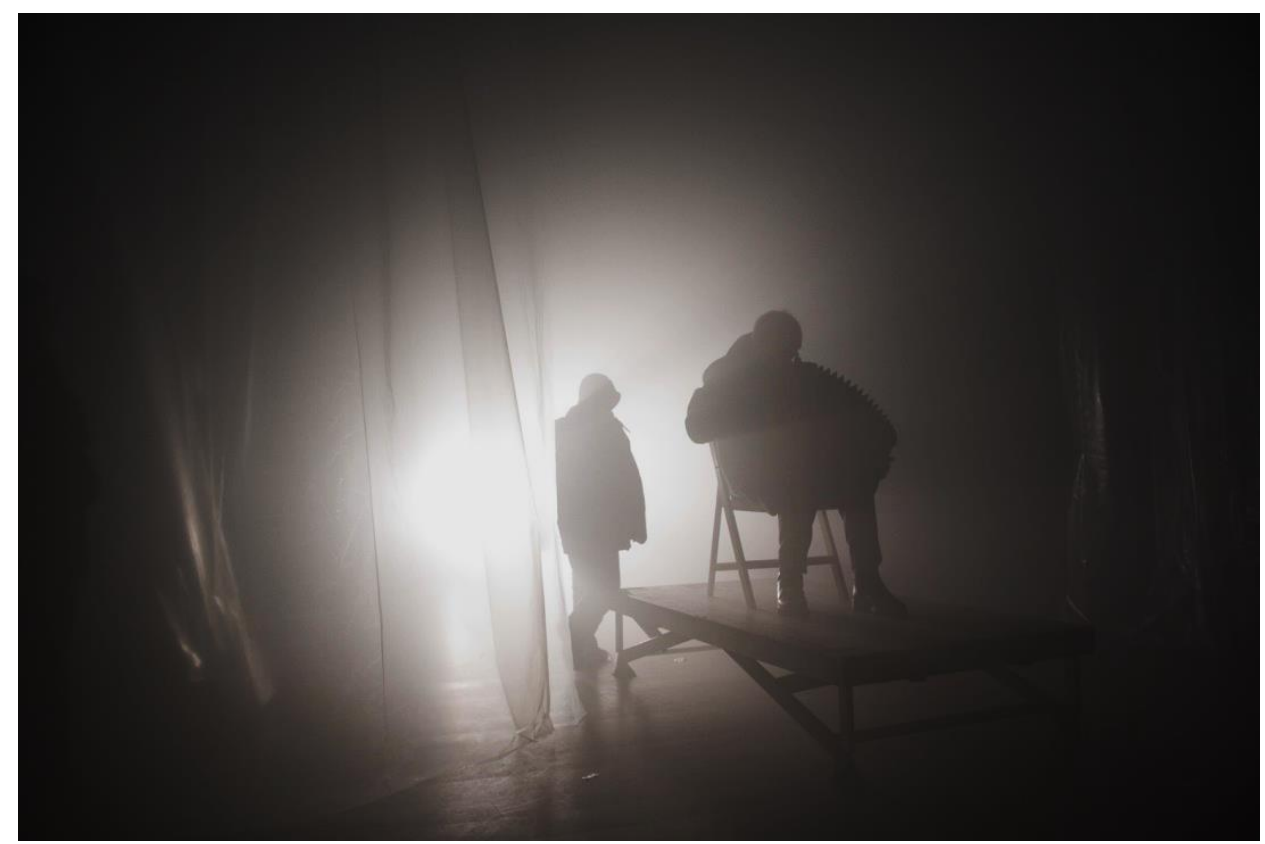

5. Christian Boltanski, Jean Kalman, Franck Krawczyk, Angelika Markul, Póki my żyjemy..., siedziba Banku Polskiego tzw. Reduta, Warszawa, 2008.

Dzięki uprzejmości Galerii Foksal 